\title{
Performance of Soybean (Glycine max) under Raised Bed Planting in Malwa region of Madhya Pradesh, India
}

\author{
S. S. Dhakad ${ }^{1 *}$, Vijay Agrawal $^{2}$, K.S. Kirar ${ }^{3}$, S.S. Chauhan ${ }^{3}$ and Sanjeev Verma ${ }^{4}$ \\ ${ }^{I}$ RVSKVV Krishi Vigyan Kendra, Shajapur (MP), India \\ ${ }^{2}$ Directorate of Horticulture and food processsing, Bhopal (MP), India \\ ${ }^{3}$ RVSKVV Krishi Vigyan Kendra, Dhar (MP), India \\ ${ }^{4} J N K V V$ Krishi Vigyan Kendra, Betul (MP), India \\ *Corresponding author
}

\section{A B S T R A C T}

Keywords

Soybean, raised bed, growth

character, yield

Article Info

Accepted:

25 February 2020

Available Online:

10 March 2020
On-Farm Testing (OFT) were conducted during the two consecutive years 2014-15 and 2015-16 at farmer's field in Shajapur district of Madhya Pradesh to assess the effect of raised bed planting on the growth characters, yield and economic parameters of soybean crop. The field trials were conducted during kharif season 2014 to 2015 for soybean crop to assess furrow irrigated raised bed (FIRB) seed cum fertilizer drill. Furrow irrigated raised bed (FIRB) seed cum fertilizer drill was found better in term of growth characters and yield of soybean in comparison with conventional seed drill. The net return is the best index of profitability of soybean crop and higher net return per ha Rs 34533 was recorded for soybean crop under raised bed planting where as lower net return per ha of Rs 18971 was recorded for soybean crop under control.

\section{Introduction}

Soybean (Glycine max L.) is an important oil seed crop. The total area under soybean cultivation in India was 10.69 mha and total production was $12.67 \mathrm{Mt}$ with productivity of $1185 \mathrm{~kg} / \mathrm{ha}$ (SOPA, 2014). The machinery such as raised bed planter, conventional seed cum fertilizer drill, ridge and furrow planter, broad bed planter and zero till seed cum fertilizer drill respectively used to sow the seed on raised bed in better pulverized soil so that the minimum compaction of soil over sown seed, promote seed emergence, higher moisture availability to the plants and better drainage facility during rainfall from furrow are available for sowing of soybean of soybean crop.

Whereas, the conventional seed cum fertilizer drill is used to sow the seed on well prepared seed bed and levelled field with minimum 
compaction of soil on the sown seed but it requires irrigation in planting for better germination. It facilitates manual and mechanical weeding between rows, optimum plant population, even with reduced seed rate, lower and more efficient seeding rate than broadcasting. Row seeding also promotes maximum tillering and better sunlight penetration.

Though the best placement depends upon the kind of crop, the nature of soil, the type of fertilizer salt and the climatic conditions, it has been conclusively proved that placing any kind of fertilizer in a band $30-50 \mathrm{~mm}$ to the side and $20-30 \mathrm{~mm}$ deep to the seed is safe and effective for most of the crops (Martin \& Leonard, 1976 and Kepner et al., 1987).

Land treatments (raised sunken bed system, ridges and furrows, broad bed and furrows) increased in situ soil moisture conservation, minimized runoff, and soil erosion (Singh et al., 1999).

Nimje et al., (2003) concluded that use of improved seeding machines such as seedcum-fertilizer drill and strip-till seed-cumfertilizer drill reduced the cost of operation by Rs 935 and Rs 1,578/ha and increased the net income by Rs 2,589 and Rs 3,703/ha, respectively, over the local seed drills used by the farmers.

They also colclude that planting density of $440,000 /$ ha increased the seed yield by $61.6 \%$ and the net returns by Rs 6,669/ha over farmers' practice in farmers field in Bhopal district. Jat and Singh (2003) reported higher biological yield and highest net and gross return from land configuration treatment as compared to conventional system has been reported. Ali and Behera (2014) reported that the performance of soybean was better in raised-bed than flat-bed conventional system of planting.
Beneficial effects of ridge and furrow method of sowing on soybean yield have been reported through an improved soil aeration, moisture, temperatures, better root development and nitrogen fixation (Tisdall and Hodgson, 1990; Jayapaul et al., 1995; Jain and Dubey, 1998; Raut et al., 2000).

Ram \& Singh. (2011) conducted an experiment on four sowing methods namely raised bed planting, raised broad bed planting, ridge-furrow. sowing and flat sowing for soybean crop. The highest seed yield was recorded in raised bed sowing, which was 6.70 and $5.29 \%$ higher than ridgefurrow and flat sowing methods, respectively.

Dhakad \& Khedkar (2014) concluded that field demonstration was conducted during kharif season 2012 to 2013 to study effect of seed-cum-fertilizer drill sowing machine for soybean crop that soybean sown by seedcum-fertilizer drill was found better in term of growth characters and economics parameters with comparison to simple seed drill sowing machine. Dhakad et al., (2019) concluded that net return is the best index of profitability of soybean crop and higher net return per ha of Rs 25144 was recorded for soybean crop under ridge and furrow seed cum fertilizer drill whereas lower net return per ha of Rs 18025 was recorded under normal seed drill sowing.

With a view to generate information, a field experiment was conducted at at farmer's fields to observe effect of seed-cum-fertilizer drill sowing machine on the growth characters and yield of soybean.

\section{Materials and Methods}

The field experiments were conducted at the farmer's fields during kharif seasons 2014 and 2015 for soybean crop in the selected village under operational area of Krishi 
Vigyan Kendra Shajapur to assess the effect of raisedbed planting on yield and economics of soybean crop. The climate of the region is tropical sub-humid receiving an rainfall of $740 \mathrm{~mm}$ and $1387 \mathrm{~mm}$ in year 2014 and 2015 respectively with maximum and minimum temperature of $45^{\circ} \mathrm{C}$ and $5^{\circ} \mathrm{C}$, respectively. The soils of experiment sites were medium black soil.

Soybean variety JS 95-60 was used during kharif 2014 and 2015. The tractor operated raised bed planter had been used in sowing of soybean in which two raised bed can be made on which planting is also carried out simultaneous. Machine can sow two rows of soybean on each bed. Fertilizer drilling can also be accomplished on the raised bed.

This raised bed planter is capable of making furrows of desired depth and width at both the sides of the bed and can be used for simultaneous sowing of crop in one operation. These furrows are useful to drain out excessive rainwater during heavy storms and for storing rainwater in furrows for enriching soil moisture through percolation in case of deficit rainfall and the soil moisture thus stored sustain the crop during dry spells (Singh et al., 2011).

Nimje et al., (2002) \& Dhakad et al., (2017) reported that effect of seed-cum-fertilizer drill sowing machine for soybean crop. The observations plant height, number of branches per plant, number of root nodules per plant, number of pods per plant, seed index, seed yield, straw yield, harvest index and economics of treatments were calculated for continuously two years for soybean crop. The parameters and procedures followed are given in table 1 .

The data collected on various characters of soybean crop was processed and subjected to statistical analysis by t test as suggested by
William Sealy Gosset (Fisher Box, Joan 1987). The experiment comprising two treatments with five replications and in this case the number of plots was $02 \times 05=10$ and degree of freedom was $8\{(5-1)+(5-1)\}$. Statistical analysis was carried out by analyze the difference between two treatments using the ' $t$ ' test of significance and the formula for $\mathrm{T}$ test is given below

$$
t=\frac{\overline{x_{1}}-\overline{x_{2}}}{\sqrt{\frac{S_{1}^{2}}{n_{1}}+\frac{S_{2}^{2}}{n_{2}}}}
$$

Where,

$\overline{\mathbf{x}}_{1}=$ Mean of first set of values

$\overline{\mathbf{x}}_{2}=$ Mean of second set of values

$\mathrm{S}_{1}=$ Standard deviation of first set of values

$\mathrm{S}_{2}=$ Standard deviation of second set of values

$\mathrm{n}_{1}=$ Total number of values in first set

$\mathrm{n}_{2}=$ Total number of values in second set.

Finally, the calculated't' value is compared with the theoretical value from a ' $t$ ' table at $5 \%$ probability level. Based on the comparison of calculated't' value with the theoretical ' $\mathrm{t}$ ' value from the table, we conclude: If the calculated " $\mathrm{t}$ " value is greater than the theoretical ' $\mathrm{t}$ ' value, then the difference between the two treatments is significant. If the calculated ' $t$ ' value is less than the theoretical ' $\mathrm{t}$ ' value, then the difference between the two treatments is not significant.

\section{Results and Discussion}

Growth and yield attributing characteristics of soybean are presented in Table 2. Table revealed that the plant growth and yield parameters were found better in raisedbed planting system as compared to ridge and furrow. Its due to proper drainage of excess rainfall through furrows and moisture 
conservation during dry spell. Similar results were reported by Ralli and Dhingra (2003) and he found that the higher nodule count under ridge sowing when compared with flat sowing for soybean crop.

The grain yield, straw yield and net monetary returns were higher under raisedbed seed cum fertilizer drill sowing compare to ridge and furrow. The highest productivity of $1644 \mathrm{~kg}$ $\mathrm{ha}^{-1}$ observed in the seed cum fertilizer drill sowing whereas lowest under normal seeddrill sowing (1235 kg ha $\left.{ }^{-1}\right)$ for soybean crop. The net return is the best index of profitability of soybean crop and higher net return per ha Rs 34533 was recorded for soybean crop under raisedbed planting where as lower net return per ha of Rs 18971 was recorded for soybean crop under ridge and furrow.The plant height, number of branches per plant, number of root nodules per plant, number of pods per plant, seed yield, straw yield and net monetary returns were statistically higher in raisedbed sowing compare to ridge and furrow for soybean crop. The analysis showed that there was no significant difference on seed index, grain straw ratio and harvest index due to treatments was observed. Nimje et al., (2002) Dhakad \& Khedkar (2014) \& Dhakad et al., (2019) also reported an increase in net income of soybean due to seed-cum-fertilizer drill.

Table.1 Details of crop growth and economic parameter

\begin{tabular}{|c|c|c|}
\hline $\begin{array}{l}\text { S. } \\
\text { No. }\end{array}$ & Parameter & Procedure followed \\
\hline 1. & Plant height & $\begin{array}{l}\text { Plant height at } 60 \text { days after sowing, and at harvest stage was } \\
\text { recorded } \\
\text { In plot five plants were selected randomly and tagged for periodic } \\
\text { observation. }\end{array}$ \\
\hline 2. & $\begin{array}{l}\text { Number of } \\
\text { branches/plant }\end{array}$ & $\begin{array}{l}\text { The five plants were randomly tagged to count the number of } \\
\text { branches per plant for all the experimental plots }\end{array}$ \\
\hline 3. & $\begin{array}{l}\text { Number of root } \\
\text { nodules/plant }\end{array}$ & $\begin{array}{l}\text { The five plants were dug up randomly from each plot and nodules } \\
\text { were counted after its washing at } 60 \text { days after sowing }\end{array}$ \\
\hline 4. & $\begin{array}{l}\text { Number of pods per } \\
\text { plant }\end{array}$ & $\begin{array}{l}\text { The total number of pods of five plants was counted and average } \\
\text { numbers of pods was calculated }\end{array}$ \\
\hline 5. & Seed index $(\mathrm{g})$ & $\begin{array}{l}\text { The weight of randomly picked } 100 \text { seeds from produce of each } \\
\text { plot was recorded }\end{array}$ \\
\hline 6. & Seed yield (kg/ha) & $\begin{array}{l}\text { The plants were harvested net plot-wise and then threshed after the } \\
\text { sun drying. }\end{array}$ \\
\hline 7. & Stover yield $(\mathrm{kg} / \mathrm{ha})$ & $\begin{array}{l}\text { The produce after harvesting were left in the field then tied the } \\
\text { bundles of each net plot for sun drying. }\end{array}$ \\
\hline 8. & Harvest Index, HI (\%) & $\begin{array}{l}\mathrm{HI}=[\text { Economic yield }(\mathrm{kg} / \mathrm{ha}) / \text { Biological yield }(\mathrm{kg} / \mathrm{ha})] \times 100 \\
\text { where, Biological yield = Grain yield }+ \text { Straw yield }\end{array}$ \\
\hline 9. & Net return (Rs/ha) & $\begin{array}{l}\text { Net return }(\mathrm{Rs} / \mathrm{ha})=\text { Gross return }(\mathrm{Rs} / \mathrm{ha})-\text { Cost of cultivation } \\
(\mathrm{Rs} / \mathrm{ha})\end{array}$ \\
\hline 10. & $\begin{array}{l}\text { Benefit cost ratio } \\
\text { (B:C) }\end{array}$ & B : C = Gross return $(\mathrm{Rs} / \mathrm{ha}) / \mathrm{Cost}$ of cultivation $(\mathrm{Rs} / \mathrm{ha})$ \\
\hline
\end{tabular}


Table.2 Growth characters and economics of soybean

\begin{tabular}{|l|c|c|c|c|}
\hline \multirow{2}{*}{ Economic parameters } & \multicolumn{3}{|c|}{ Two year pool data for Soybean } \\
\cline { 2 - 5 } & $\begin{array}{c}\text { Raisedbed } \\
\text { planting }\end{array}$ & $\begin{array}{c}\text { Ridge and } \\
\text { furrow }\end{array}$ & $\begin{array}{c}\% \\
\text { increase }\end{array}$ & $\begin{array}{c}\text { CD } \\
\text { at 5\% }\end{array}$ \\
\hline Plant height at harvesting (cm) & 64.8 & 56.2 & 15.30 & S \\
\hline $\begin{array}{l}\text { Number of Branches per plant at 60 } \\
\text { DAS }\end{array}$ & 4.02 & 3.82 & 5.24 & S \\
\hline $\begin{array}{l}\text { Number of root nodules per plant at } \\
\text { 60 DAS }\end{array}$ & 36.4 & 28.6 & 27.27 & S \\
\hline $\begin{array}{l}\text { Number of pods per plant at } \\
\text { harvesting }\end{array}$ & 48.4 & 36.4 & 32.97 & S \\
\hline Seed Index (g) & 10.4 & 10.2 & 1.96 & NS \\
\hline Grain yield (kg/ha) & 1644 & 1235 & 33.12 & S \\
\hline Straw yield (kg/ha) & 2032 & 1560 & 30.26 & S \\
\hline Grain straw ratio & 0.8 & 0.79 & 1.27 & NS \\
\hline Harvest index (\%) & 44.7 & 44.1 & 1.36 & NS \\
\hline Net monetary returns (Rs/ha) & 34533 & 18971 & 82.03 & S \\
\hline Benefit: cost ratio & 2.76 & 1.99 & 38.69 & S \\
\hline
\end{tabular}

Effect of raisedbed planting in soybean crop found better in comparison over control due to safe removal of excess rain water, soil moisture stored sustains the soybean crop during dry spells, proper aeration in root zone of soybean crop. The results of experiment indicate that for achieving higher productivity of soybean crop, the soybean crop should be sown by raisebed planter seed drill.

\section{References}

Ali, M. and Behera, U.K. 2014. Tillage and weed management for improving productivity and nutrient uptake of soybean.Indian Journal of Weed Science 46: 184-186

Dhakad, S.S. and Khedkar, N.S. 2014. Influence of seed-cum-fertilizer drill machine on the growth characters and yield of soybean (Glycine max L.) at farmer's fields. Internat. J. Forestry \& Crop Improv., 5 (2) : 68-72

Dhakad S.S., G.R. Ambawatia and N.S. Khedkar 2017. Effect of seed cum fertilizer drill on Growth Characters and Yield of Soybean (Glycine Max) in Shajapur District of Madhya Pradesh. International Journal of Agricultural Engineering, 10(1) : 16-21

Dhakad, S.S., G.R. Ambawatia, Mukesh Singh and Gayatri Verma. 2019. Effect of Ridge and Furrow Seed cum Fertilizer Drill on Growth Characters and Yield of Soybean (Glycine max) in Shajapur District of Madhya Pradesh, India. Int.J.Curr.Microbiol.App.Sci. 8(04): 2298-2304. 
Fisher Box Joan. Guinness, Gosset, Fisher, 1987. Small Samples. Statistical Science 2 (1): $\quad 45-52$

Jat, L.N. and Singh, S.M. 2003. Varietal suitability, productivity and profitability of wheat (Triticum species) intercrops and relay cropping under furrowirrigated raised bed system. Indian Journal of Agriculture Sciences 73(4):187-190

Jain, M.P. and Dubey, A.K. (1998). Productivity and economic viability of soybean with respect to planting systems and cultivars in Vertisol. Crop Research 16:102-22.

Jayapaul, P., Uthayakumar, B., Devasagayam, M.M., Pandit, B.J., Palchamy, A. and Balakrishanan, A. (1995). Effect of land configuration methods, irrigation regimes and soil moisture conservation amendments on soybean (Glycine max L. Merrill) yield and quality characters. Crop Research 11: 253-57.

Kepner RA; Bainer R; Barger EL. (1987). Principles of Farm Machinery. 1st Indian edn. CRS Publishers and Distributors, Delhi.

Martin JH; Leonard WHO.(1976). Principles of Field Crop Production. 3rd edn. The Macmillan Co., London, 1118

Nimje P.M., Agrawal Vijay, Soni R.D.(2003). Effect of planting density and improved seeding machinery on yield and economics of soybean (Glycine max). Indian Journal of Agronomy.48 (4):301-
304

Raut, V. M., Taware, S.P. and Varghese, P. (2000). Comparison of different sowing methods in soybean. Journal of Maharashtra Agricultural University 25: 218-219.

Ram H., Singh G. (2011), Soybean (Glycine max) growth, productivity and water use under different sowing methods and seeding rates in Punjab, Indian journal of Agronomy, 56 (4): 377-380.

Ralli S and Dhingra K K 2003. Response of soybean to different planting methods. Annals of Biology 19(2): 151-155.

SOPA (2014). Available from: http://www.sopa.org/crop\%20 report $\% 202014$.pdf.

Singh DevVrat, Vyas A K, Gupta G K, Ramteke R and Khan I R 2011. Tractor-drawn broad bed furrow seed drill machine to overcome moisture stress for soybean (Glycine max) in vertisols. Indian Journal of Agricultural Sciences, 81(10): 941-944.

Singh P, Alagarswamy G, Pathak P, Wani S P, Hoogenboom $G$ and Virmani S M (1999). Soybean-chickpea rotation on Vertic Inceptisol: I. Effect of soil depth and landform on light interception, water balance and crop yields. Field Crops Res 63: 211-224.

Tisdall, J. M. and Hodgson, A.S. (1990). Ridge tillage in Australia: A review. Soil \& Tillage Research 18: 127-44.

\section{How to cite this article:}

Dhakad. S. S., Vijay Agrawal, K.S. Kirar, S.S. Chauhan and Sanjeev Verma. 2020. Performance of Soybean (Glycine max) under Raised Bed Planting in Malwa region of Madhya Pradesh, India. Int.J.Curr.Microbiol.App.Sci. 9(03): 3181-3186. doi: https://doi.org/10.20546/ijcmas.2020.903.364 